\title{
Analisis Kesalahan Kalimat dalam Karangan Narasi Siswa Kelas V SDN Semeru 1 Bogor
}

\author{
Tustiyana Windiyani \\ Universitas Pakuan \\ windysoft71@yahoo.com
}

\begin{abstract}
Abstrak
Penelitian ini bertujuan untuk mendeskripsikan analisis kesalahan kalimat pada karangan narasi siswa kelas V dari aspek kesepadanan dan kesatuan, kesejajaran bentuk, penekanan dalam kalimat, kehematan, dan kecermatan dalam pilihan kata. Penelitian ini merupakan penelitian kualitati. .Metode yang digunakan dalam penelitian ini adalah metode analisis kualitatif dengan mencari dan menganalisis data yang berhubungan dengan kesalahan kalimat efektif. Subyek penelitian ini adalah siswa kelas V SDN Semeru 1 Bogor. .Berdasarkan hasil penelitian ditemukan 60 kesalahan dari 30 karangan narasi siswa. Kesalahan kalimat efektif pada karangan narasi siswa kelas V SDN Semeru 1 Bogor dari aspek kesepadanan dan kesatuan sebanyak 3 kalimat (5\%), dari aspek kesejajaran bentuk sebanyak 2 kalimat (4\%), dari aspek penekanan sebanyak 3 kalimat (5\%) aspek kehematan sebanyak 22 kalimat (36\%), dan dari aspek kecermatan sebanyak 30 kalimat (50\%). Dengan demikian dapat disimpulkan bahwa kesalahan kalimat efektif pada karangan narasi siswa kelas V SDN Semeru 1 Bogor paling banyak dilihat dari aspek kecermatan meliputi kekurangtepatan pilihan kata.
\end{abstract}

Kata Kunci: Kesalahan Kalimat, Narasi, Siswa.

\section{A. Pendahuluan}

Penguasaan bahasa tulis mutlak diperlukan dalam kehidupan modern sekarang ini, ternyata keterampilan menulis kurang mendapat perhatian. Guru merupakan salah satu tugas untuk melatih keterampilan menulis siswa, dan tentunya perlu memahami dengan baik keterampilan menulis. Pemahaman konsep menulis menjadi penting bagi siswa karena dalam praktik kesehariannya banyak siswa yang terampil membaca tetapi mengalami kesulitan dalam menulis. Penulis hendaknya menguasai cara penulisan sebagai intonasi atau jeda dalam tulisan agar tulisanya mudah untuk dipahami. Ucapan lisan agak sulit untuk dituangkan ke dalam tulisan karena segala intonasi yang terdapat dalam bahasa lisan itu akan sukar untuk diungkapkan dalam bahasa tulisan. Untuk menutupi kesukaran itulah pemahaman penulisan kalimat sangat dibutuhkan sebagai kunci atas apa yang ingin disampaikan oleh penulis kepada pembaca. 
Salah satu fungsi Bahasa Indonesia adalah sebagai alat komunikasi antar anggota masyarakat, baik secara lisan atau secara tulisan tergantung pada situasi komunikasi. Apabila situasi komunikasi itu tidak memungkinkan dipakai secara lisan, maka dipakailah secara tulisan. Sarana untuk berkomunikasi antarmanusia agar memperoleh informasi yang penting adalah dengan bahasa. Melalui pengajaran Bahasa Indonesia di sekolah siswa dapat memiliki pengetahuan tentang Bahasa Indonesia.Mampu bersikap positif terhadap nilai Bahasa Indonesia dan dapat mencintai Bahasa Indonesia sebagai salah satu bahasa dari budaya bangsa.

Komunikasi secara lisan, menghendaki adanya orang kedua, teman berbicara yang berada di depan pembicara, dalam situasi lisan antara lain berupa gerakan-gerakan anggota tubuh yang menyertai pembicara, intonasi, mimik, dan sebagainya. Berbeda dengan komunikasi tulis, tidak mengharuskan adanya teman bicara berada di depan. Namun dalam penulisan, kelengkapan unsur sebuah kalimat sangat menentukan kejelasan sebuah kalimat atau kata tersebut. Kalimat lengkap tersebut harus ditulis sesuai dengan aturan-aturan ejaan yang disempurnakan (EYD).

Menulis merupakan pengetahuan yang mendasari seluruh kegiatan dalam pendidikan. Menulis bukan menghasilkan tulisan semata, melainkan suatu tindakan aktif yang dihasilkan dari hasil curahan pikiran yang mengandung makna, sehingga mudah dipahami oleh orang lain (pembaca). Kegiatan menulis bagi siswa mempunyai fungsi utama sebagai sarana belajar. Bentuk tulisan yang baik adalah tulisan yang memperhatikan penggunaan tanda baca. Penggunaan kalimat dan lain-lain. Penulisan huruf kapital dan kalimat-kalimat yang digunakan perlu ditingkatkan dan dimengerti oleh setiap pemakai Bahasa Indonesia, khususnya bagi siswasiswi, tidak hanya huruf kapital saja, penggunaan kalimat yang digunakan pun bervariasi perlu dipahami untuk menunjang peningkatan keterampilan dalam berbahasa.

Peneliti telah melakukan observasi awal ke SDN Semeru 1 kelas V pada tanggal 17 Mei 2017 berdasarkan hasil observasi yang telah dilakukan dengan guru-guru di SDN Semeru 1. Mengenai karangan pembelajaran Bahasa Indonesia para siswa belum bisa mengetahui kalimat yang baku untuk digunakan dalam membuat karangan narasi yang mereka buat. Subyek penelitian yang akan diteliti oleh peneliti difokuskan pada bentuk kesalahan kalimat dan jenis kalimat apa saja yang paling dominan. Masalah yang menjadi latar belakang dalam penelitian ini yaitu penggunaan atau bentuk kalimat yang sesuai dengan ejaan yang disempurnakan (EYD).Salah satunya yang ditemui berbagai bentuk kalimat pada teks narasi siswa kelas V SDN Semeru 1 Bogor.Kesalahan ini perlu diperhatikan agar nantinya tidak terjadi kesalahan 
seterusnya.Pada penelitian ini, peneliti mengkaji lebih dalam pada penggunaan Kalimat. Tujuan dalam penelitian ini: (1) mengetahui bentuk kesalahan kalimat dalam karangan yang dibuat siswa kelas V di SDN Semeru 1, (2) mengetahui jenis kalimat yang paling dominan dalam karangan narasi siswa kelas V di SDN Semeru 1.

\section{B. Kajian Pustaka}

Ellis dalam Tarigan, (2011:153). menyatakan bahwa analisis kesalahan berbahasa adalah suatu prosedur yang biasa digunakan oleh para peneliti dan guru bahasa, yang meliputi pengumpulan sampel bahasa pelajar, pengenalan kesalahan-kesalahan yang terdapat pada sampel tersebut, pendeskrifsian kesalahan-kesalahan itu, pengklarifikasianya berdasarkan sebabsebabnya yang telah di hipotesiskan, serta pengevaluasian keseriusannya.

Dalam buku yang berjudul Interoduction Applied linguistics oleh Corder yang dikutip kembali oleh Yuniseffendri (2001:1), menyatakan bahwa yang dimaksud dengan kesalahan berbahasa adalah pelanggaranterhadap kode bahasa. Berdasarkan pendapat-pendapat tersebut dapat diketahui bahwa kesalahan berbahasa merupakan pelanggaran pada kode-kode bahasa. Kode bahasa yaitu aturan- aturan yang telah disepakati pengguna bahasa untuk maksud tertentu. Analisis kesalahan berbahasa merupakan suatu "proses" Tarigan (2011:152) menjelaskan sebagai suatu proses, maka ada prosedur yang harus dituruti selaku pedoman kerja, dengan demikian, analisis kesalahan berbahasa mempunyai langkah-langkah tertentu.

Di dalam memberikan indikasi atau petunjuk kepada guru dan para pengembang kurikulum, bagaimana dari bahasa sasaran yang paling sukar diproduksi oleh para pelajar secara baik dan benar, serta tife kesalahan mana yang paling menyukarkan atau mengurangi kemampuan pelajar untuk berkomunikasi secara efektif. Ellis (dalam Tarigan dan Tarigan, 2011:67) menyatakan terdapat lima langkah kerja analisis, yaitu: (1) pengumpulan sampel, (2) pengidentifikasian kesalahan, (3) penjelasan kesalahan, (4) pengklasifikasian kesalahan, dan (5) pengevaluasian kesalahan.

Dalam buku Pengajaran Analisis Kesalahan Berbahasa karangan Tarigan dan Tarigan (2011:179-182), terdapat empat jenis kesalahan berbahasa, yaitu: (1) kesalahan fonologi, (2) kesalahan morfologi, (3) kesalahan sintaksis, dan (4) kesalahan leksikon. Gantamitreka, (2016:170-176) menyatakan sebuah kalimat harus berisikan suatu gagasan atau ide. Agar gagasan atau ide kalimat mudah dipahami pembaca, fungsi bagian kalimat yang meliputi subjek, predikat, objek, dan keterangan harus tampak jelas selain itu, kalimat harus disusun secara logis 
dan teratur, yaitu (1) kalimat tidak bersubjek, (2) kalimat yang dipenggal-penggal, (3) padanan yang tidak sepadan atau serasi, (4) penyusunan kalimat majemuk, (5) mengutip pendapat orang lain.

Finoza (2008:172) memaparkan bahwa pengertian kalimat efektif adalah kalimat yang dapt mengungkapkan maksud penutur/penulis secara tepat sehingga maksud itu dapat dipahami oleh pendengar/pembaca secara tepat pula. Selaras dengan Finoza, Faud dan kawan-kawan dalam (Dalman, 2014:21) mengemukakan bahwa "kalimat efektif adalah yang memiliki kemampuan untuk menimbulkan kembali gagasan-gagasan pada pikiran pendengaran atau pembaca seperti apa yang ada dalam pikiran pembicara atau penulis.' Pendapat ini memperkuat pendapat Finoza mengenai pengertian kalimat efektif.

Pengertian kalimat efektif menurut Widjono (2011:160) adalah kalimat yang singkat, padat, jelas, lengkap, dan dapat menyampaikan informasi secara tepat. Kalimat efektif dapat mengomunikasikan pikiran atau perasaan penulis atau pembicara kepada pembaca atau pendengar secara tepat. Ansori (2009:49) menjelaskan Menulis adalah kegiatan berpikir di atas kertas dan berkomunikasi dengan orang lain. Untuk itu, dalam kegiatan ini pengetahuan dan keterampilan berbahsa merupakan hal penting. Tidak hanya kemampuan merangkai kata secara terstruktur, tetapi harus ada unsur lain yang mengikutinya.

Arifin (2009:134) mengungkapkan ciri khas kalimat efektif adalah sebagai berikut: (1) kesepadanan struktur, (2) keparalelan, (3) ketegasan, (4) kehematan, (5) kecermatan, dan (6) kepaduan. Pendapat para ahli di atas memiliki persamaan dalam memberikan definisi kalimat efektif. Secara sederhana, kita dapat menyimpulkan bahwa kalimat efektif adalah kalimat yang memiliki kemampuan untuk menimbulkan kembali gagasan-gagasan pada pikiran pendengar atau pembaca seperti apa yang ada dalam pikiran pembicara atau penulis.

Semi (2007:53) menjelaskan narasi ialah tulisan yang tujuannya menceritakan kronologis peristiwa kehidupan manusia. Oleh sebab itu karangan narasi sering juga disebut karangan cerita. Kekuatan karangan itu terletak pada urutan cerita berdasarkan waktu dan cara-cara bercerita yang diatur melalui alur (plot). Unsur pelaku atau tokoh merupakan pokok yang dibicarakan. Sedangkan unsur peristiwa merupakan hal-hal yang dialami oleh sang tokoh. Sasaran karangan narasi umumnya ditunjukkan pada aspek emosi. Aspek intelektual tidak banyak digunakan dalam karangan ini. Jadi, dengan narasi diharapkan penerima dapat membentuk citra atau imajinasi. 
Sebuah cerita, unsur utamanya adalah waktu dan perbuatan, keduanya dijalin secara utuh. tergantung pada tujuan penulis. Pada umumnya tulisan narasi bertujuan menceritakan objek secara lengkap dan jelas dan memberikan pengalaman estetika. Menulis karangan yang baik dan benar tidak mungkin hanya sekali membuat akan langsung menghasilkan tulisan yang bagus dan benar. Perlu diketahui langkah-langkah dalam membuat karangan narasi. Zulela (2012:74) menyebutkan Langkah-langkah menulis fiksi yaitu: (1) menentukan tema (Pesan) yang menjiwai seluruh isi cerita), (2) menentukan tokoh cerita, (3) enulis draf plot/alur cerita; kapan cerita itu berawal, klimaks dan akan berakhir bagaimana cerita itu, sesuaikan dengan tema yang telah ditentukan, (4) pilih/gunakan gaya bahasa. Pilihan kata yang sederhana yang mudah dipahami anak (SD), dan akan lebih baik bila penulis survey dahulu bagaimana sebenarnya kondisi tokoh yang diangkat, (5) pengembangan cerita; mendeskrifsikan cerita dengan bahasa.

\section{Metode Penelitian}

Penelitian ini dilaksanakan di SD Negeri Semeru 1 Bogor yang berlokasi di Jalan Medika Nomor 2C Kelurahan Menteng Kecamatan Bogor Barat, Kota Bogor di kelas V-a dan VC Semester Ganjil Tahun Pelajaran 2017/2018. Subjek penelitian ini terdiri dari 30 siswa kelas V di SDN Semeru 1 Bogor.Metode penelitian yang digunakan metode kualitatif Bogdan dan Taylor dalam Moleong (2002:3) mendefinisikan penelitian kualitatif adalah penelitian yang menghasilkan data deskriptif berupa kata-kata tertulis atau lisan dari seseorang atau perilaku yang dapat diamati. Berdasarkan definisi tersebut dapat dijelaskan unsur-unsur pokok kualitatif meliputi: penelitian yang menekankan kealamiahan data, sehingga ada pengkondisian tertentu pada objek; (2) peneliti sendiri bertindak sebagai instrument kunci dalam mendapatkan data; (3) di lapangan memerlukan interaksi secara intensif dan waktu yang lama; (4) datanya berupa katakata tertulis atau lisan dari orang atau perilaku yag dapat diamati; (5) pendekatan yang bersifat induktif; dan (6) hasil penelitian yang menekankan makna.

Pada tahapan penelitian kualitaif ini dilakukan observasi terlebih dahulu untuk menemukan permasalahan yang terjadi. Setelah ditemukan permasalahan yang akan diteliti, maka dilakukan pengamatan terhadap masalah yang menjadi sumbernya. Peneliti melakukan obsevasi dengan mengecek lembaran kerja siswa untuk menganalisis variasi kalimat dengan melihat hasil karangan siswa tersebut. 
Data penelitian ini berupa kesalahan kalimat efektif yang dibuat secara tertulis dalam bentuk karangan narasi siswa kelas V. Teknik dan prosedur pengumpulan dan perekaman data melalui: observasi, pencatatan, dan dokumen (hasil karangan siswa/foto. gambar proses). Penelitian ini menggunakan juga jenis triangulasi penyidik, yaitu mengadakan pengecekan dengan peneliti lain. Dalam hal ini, penulis melakukan diskusi kepada tiga orang narasumber yang masing-masing memiliki keterkaitan dengan bidang ilmu kebahasaan dan kesastraan yang cukup kompeten untuk mampu meneliti data yang penulis sajikan kepada objek peneliti tersebut.

\section{Pembahasan}

Klasifikasi kesalahan dari hasil penelitian yaitu pertama dilihat dari aspek kesepadanan dan kesatuan terdiri dari 3 kesalahan, kedua dilihat dari aspek kesejajaran bentuk terdiri dari 2 kesalahan, ketiga dilihat dari aspek penekanan terdiri dari 3 kesalahan, keempat dilihat dari aspek kehematan terdiri dari 22 kesalahan, dan kelima dilihat dari aspek kecermatan terdiri dari 30 kesalahan. Jumlah kesalahan dapat dipresentasikan sebagai berikut:

E.

\section{Tabel 4.1 Presentase Hasil Analisis Jenis-Jenis Kesalahan Kalimat Efektif}

\begin{tabular}{|l|l|c|c|}
\hline No & Jenis Kesalahan Kalimat & Jumlah Kesalahan & Jumlah (\%) \\
\hline 1 & Kesepadanan dan kesatuan & 3 & 5 \\
\hline 2 & Kesejajaran bentuk & 2 & 4 \\
\hline 3 & Penekanan & 3 & 5 \\
\hline 4 & Kehematan & 22 & 36 \\
\hline 5 & Kecermatan & 60 & 100 \\
\hline & Jumlah & 30 & 50 \\
\hline
\end{tabular}

Kesepadanan dan kesatuan sebanyak 3 kalimat (5\%); jenis kesalahan kalimat efektif dari aspek kesejajaran bentuk sebanyak 2 kalimat (4\%); jenis kesalahan kalimat efektif dari aspek penekanan sebanyak 3 kalimat (5\%); jenis kesalahan kalimat efektif dilihat dari aspek kehematan sebanyak 22 kalimat (36\%); dan jenis kesalahan kalimat efektif dilihat dari aspek kecermatan sebanyak 30 kalimat (50\%). Berdasarkan analisis data dilakukan peneliti, jenis kesalahan kalimat efektif yang paling banyak adalah jenis kesalahan kalimat dari segi kecermatan yaitu sebanyak 30 kalimat (50\%).

Triangulasi merupakan suatu langkah dalam upaya memeriksa sebuah keabsahan data penelitian. Dalam penelitian ini, peneliti meminta bantuan kepada SK dan AS selaku dosen 
Bahasa Indonesia di FKIP, Universitas Pakuan dan EW selaku guru Bahasa Indonesia. Adapun hasil triangulasi yang dilakukan narasumber sebagai berikut: (1) SC menyetujui semua kutipan karangan narasi yang dijadikan penelitian oleh peneliti. Jika dipersentasekan, SC menyetujui hasil analisis penelitian sebanyak 100\%, (2) AS menyetujui kutipan karangan narasi yang dijadikan penelitian oleh peneliti meskipun 1 kutipan dari kehematan dan 1 kutipan dari kecermatan tidak disetujui karena berbeda prinsip mengenai pengelompokan aspek kalimat efektif. Jika dipersentasekan, AS tidak menyetujui hasil analisis penelitian sebanyak $2 \%$, sedangkan sisanya 98\% AS menyetujuinya, dan (3) EW menyetujui kutipan karangan narasi yang dijadikan penelitian oleh peneliti meskipun 2 kutipan kehematan dan 1 kutipan kecermatan tidak disetujui karena tidak sesuai dengan teori yang ada. Jika dipersentasekan, EW tidak menyutujui hasil analisis penelitian sebnayak 3\%, sedangkan sisanya 97\% EW menyetujui.

\section{F. Simpulan}

Berdasarkan hasil penelitian dan pembahasaan, dapat ditarik simpulan sebagai berikut: (1) dari tiga puluh karangan narasi siswa yang dijadikan sampel terdapat 60 kesalahan kalimat efektif. Hal tersebut terjadi karena masih ditemukan pola kalimat yang belum tepat, dan (2) Adapun kesalahan kalimat efektif pada karangan narasi siswa kelas V SDN Semeru 1 Bogor meliputi; pertama diliha tdari aspek kesepadanan dan kesatuan terdiri dari 3 kesalahan (5\%), kedua dilihat dariaspek kesejajaran bentuk terdiri dari 2 kesalahan (4\%), ketiga dilihat dariaspek penekanan sebanyak 3 kesalahan (5\%), keempat dilihat dariaspek kehematan sebanyak 22 kesalahan (36\%), dan kelima dilihat dariaspek kecermatan sebanyak 30 kesalahan (50\%). Dari kelima ciri kalimat efektif paling banyak pada segi aspek kecermatan meliputi kekurangtepatan pilihan kata.Kesalahan-kesalahan disebabkan karena keterbatasan pemahaman pada aturan berbahasa.

\section{Daftar Pustaka}

Arifin dan Amran Tasai. 2012. Bahasa Indonesia. Jakarta: Pustaka Mandiri

Dalman.2016. Keterampilan Menulis. Jakarta: PT Raja Grafindo Prasada

Finoza, Lamuddin. 2013. Komposisi Bahasa Indonesia. Jakarta: Diksi. 
Gantamitreka. 2016. Kesalahan Berbahasa Penggunaan EYD. Genta Smart Publisher: Solo

Moleong,Lexy .2007. Metodologi Penelitian Kualitatif. Bandung: PT Remaja Rosdakarya

Semi.2007.Dasar-Dasar Keterampilan Menulis. Bandung: Angkasa

Tarigan, Henry Guntur dan Djago Tarigan.2011.Pengajaran Analisis Kesalahan Berbahasa. Bandung: Angka

Widjono.2012 .Bahasa Indonesia. Jakarta: PT Grasindo

Yuniseffendri. 2001.Buku Ajar Analisis Kesalahan Berbahasa. Bogor: Universitas Pakuan. 